\title{
Hot Tearing Evaluation of Al - Based Alloys
}

Marek Bruna, Augustín Sládek

Department of technological engineering, University of Žilina. Univerzitná 8215/1, 01026 Žilina, Slovak republic. Email: rapture.marko@gmail.com,Augustin.sladek@fstroj.uniza.sk

Hot tearing during solidification of aluminium alloys castings can be a serious problem. This phenomenon is well known but still insufficiently investigated. Hot tearing occurs in form of irregular cracks in metal castings that develop during solidification and cooling (typically while the casting is still inside the mold or die cavity). The cause of hot tearing is generally attributed to the development of thermally induced tensile stresses and strains in a casting as the molten metal contracts during solidification and solid state shrinkage. Submited paper consists of two parts. The first part introduces the reader to the phenomenon of hot tearing. The second part describes newly developed method for assessing hot tearing susceptibility of aluminium alloys, and also gives the results on hot tearing for various aluminium alloys.

Keywords: Hot tearing, Al alloys, Freezing range, Chemical composition

\section{References}

[1] ESKIN, D. G., KATGERMAN. L. (2007). A Quest for a New Hot Tearing Criterion. In: Metallurgical and Materials Transactions $A, 38,1511-1514$.

[2] KNEISSL, C., PABEL, T., DAMBAUER, G., SCHUMACHER, P. (2009). Formenkonzept und Ergebnisse gießtechnologischer Versuche zur Legierungsentwicklung im Niederdruckkokillenguss, Giesserei-Rundschau, 56, 120-125.

[3] PASTIRČÁK, R., KRIVOŠ, E. (2013). Effect of opening material granularity on the mould properties and the quality of casting made by patternless process technology. In Manufacturing Technology: Journal for science research and production. Vol.13, no. 1, pp. 92-97, ISSN 1213-2489.

[4] MEŠKO, J., ZRAK, A., MULCZYK, K., TOFIL, S. (2014). Microstructure analysis of welded joints after laser welding, In: Manufacturing Technology: journal for science, research and production, Vol. 14, No. 3 (2014), s. 355- 359. ISSN 1213-2489, Kód: ADM.

[5] PASTIRČÁK, R. (2014). Effect of low pressure application during solidification on microstructure of AlSi alloys. In: Manufacturing Technology. ISSN 1213-2489. Vol. 14, No. 3 (2014), p. 397-402.

[6] BOLIBRUCHOVÁ, D., ŽIHALOVÁ, M. (2013). Possibilities of iron elimination in aluminium alloys by vanadium. In: Manufacturing technology. Vol. 13, No. 3, pp. 289 -296.

[7] ŽMINDÁK, M., MEŠKO, J., PELAGIC, Z., ZRAK, A. (2014). Finite element analysis of crack growth in pipelines. In: Manufacturing Technology. 2014, Vol. 14, No. 1, pp. 116-122. JEPU in Usti nad Labem. Czech Republic

[8] BOLIBRUCHOVÁ, D., RICHTÁRECH, L. 2013. Effect of adding iron to the AlSi7Mg0.3 (EN AC 42 100, A356) alloy. In: Manufacturing Technology. ISSN 1213-2489. Vol. 13, No. 3, p. 276-281. 